\title{
Postharvest quality and brown rot incidence in plums treated with Ascophyllum nodosum extract
}

\section{Qualidade pós-colheita e incidência de podridão parda em ameixas tratadas com extrato de Ascophyllum nodosum}

\author{
Thayna Viencz ${ }^{1 *}$; Ires Cristina Ribeiro Oliari²; Ricardo Antonio Ayub ${ }^{3}$; Cacilda \\ Márcia Duarte Rios Faria ${ }^{4}$; Renato Vasconcelos Botelho ${ }^{4}$
}

\begin{abstract}
Highlights:
Application of the extract of Ascophyllum nodosum on postharvest 'Irati' plums increased the total phenolic compound content and polygalacturonase (PG) activity.

In 'Reubennel' plums, treatment with $A$. nodosum extract led to higher titratable acidity, a lower TSS/TA ratio, lower pulp firmness and higher pectin methylesterase (PME) activity.

Treatment with $A$. nodosum extract at $0.4 \mathrm{~mL} \mathrm{~L}^{-1}$ reduced the incidence and severity of brown rot by approximately $50 \%$ in 'Reubennel' plums.
\end{abstract}

\begin{abstract}
The use of extracts of algae in agriculture has been growing because of their benefits to plant development and production. The objective of this study was to evaluate the effects of Ascophyllum nodosum extract on the postharvest quality of 'Irati' and 'Reubennel' plums and on the incidence of brown rot. The treatments consisted of concentrations of $0,0.1,0.2,0.3$ and $0.4 \mathrm{~mL} \mathrm{~L}^{-1}$ of a commercial product containing algae extract $\left(\right.$ Algamare $\left.^{\circledR}\right)$ that were applied to the fruits by immersion. The fruits were then stored for 15 (cv. Irati) or 30 days (cv. Reubennel) at $2.5^{\circ} \mathrm{C}$ and $90 \% \mathrm{RH}$ and for two additional days at ambient conditions for further physicochemical analysis. A batch of 'Reubennel' plums was inoculated with Monilinia fructicola and kept for seven days in a cold room and an additional nine days at room temperature to evaluate the occurrence of brown rot. The postharvest application of the extract at a concentration of $0.4 \mathrm{~mL} \mathrm{~L}^{-1}$ altered some of the physicochemical characteristics of the fruit after storage; an increase in the total phenolic compound content and PG activity were observed in 'Irati' plums. Reubennel fruits had higher titratable acidity, a lower TSS/TA ratio, lower pulp firmness and higher PME activity. The most significant effect was observed with the application of $A$. nodosum extract at $0.4 \mathrm{~mL} \mathrm{~L}^{-1}$, which significantly reduced the incidence and severity of brown rot in the inoculated fruits and had a similar control effect as the application of the fungicide iprodione.
\end{abstract}

Key words: Enzymatic activity. Monilinia fructicola. Postharvest diseases. Prunus salicina.

\footnotetext{
1 Discente do Curso de Doutorado do Programa de Pós-Graduação em Ciência de Alimentos, Universidade Estadual de Londrina, UEL, Londrina, PR, Brasil. E-mail: thayviencz@hotmail.com

${ }^{2}$ M.e, Empresa de Pesquisa Agropecuária e Extensão Rural de Santa Catarina, EPAGRI, Gerência Regional de Xanxerê, Ipuaçu, SC, Brasil. E-mail: iresoliari@epagri.sc.gov.br

3 Prof. Dr., Universidade Estadual de Ponta Grossa, UEPG, Ponta Grossa, PR, Brasil. E-mail: rayub@uepg.br

4 Profs. Drs., Universidade Estadual do Centro-Oeste, UNICENTRO, Guarapuava, PR, Brasil. E-mail: cfaria@unicentro.br; rbotelho@unicentro.br

* Author for correspondence
} 


\section{Resumo}

O uso de extratos de algas na agricultura vem crescendo devido aos benefícios no desenvolvimento e produção das plantas. O objetivo do estudo foi avaliar o efeito do extrato de Ascophyllum nodosum na qualidade pós-colheita de ameixas 'Irati' e 'Reubennel' e na incidência de podridão parda. Os tratamentos consistiram de concentrações de $0,0,1,0,2,0,3$ e $0,4 \mathrm{~mL} \mathrm{~L}^{-1}$ de produto comercial contendo extrato de algas $\left(\right.$ Algamare $^{\circledR}$ ) que foram aplicados por imersão nos frutos e posterior armazenamento por 15 (cv. Irati) ou 30 dias (cv. Reubennel) a $2,5^{\circ} \mathrm{C}$ e $90 \%$ de UR e dois dias adicionais em condições ambiente, para posterior análises físico-químicas. Um lote de ameixas 'Reubennel' foi inoculado com Monilinia fructicola, mantido por sete dias em câmara fria e mais nove dias à temperatura ambiente para avaliar a ocorrência de podridão parda. A aplicação pós-colheita do extrato com a dose de $0,4 \mathrm{~mL} \mathrm{~L}^{-1}$ alterou algumas características físico-químicas após o armazenamento, como o aumento no teor total de compostos fenólicos e a atividade da enzima PG para as ameixas 'Irati'. Para a cv. Reubennel, os frutos apresentaram maior acidez titulável, menor relação SST/AT, menor firmeza de polpa e maior atividade da enzima PME. O efeito mais significativo foi verificado pela aplicação do extrato de A. nodosum a $0,4 \mathrm{~mL} \mathrm{~L}^{-1}$, que reduziu significativamente a incidência e a severidade da podridão parda em frutos inoculados, com controle semelhante à aplicação do fungicida iprodione.

Palavras-chave: Atividade enzimática. Monilinia fructicola. Podridões. Prunus salicina.

\section{Introduction}

Stone fruits such as plums, peaches and nectarines are climacteric and highly perishable due to their rapid maturation and senescence (Crisosto \& Mitchell, 2011; Kader, 2011). In addition, they are highly susceptible to brown rot, one of the most important diseases of the Prunus genus, both in commercial plantations and postharvest (Bosshard, Hilber-Bodmer, Schärer, Bünter, \& Duffy, 2006; De Cal, Gell, Usall, Viñas, \& Melgarejo, 2009; May de Mio, Luo, \& Michailides, 2011). Brown rot is caused by three species of fungi in the Monilinia genus: M. fructicola, M. laxa and M. frutigena (May de Mio, Garrido, \& Ueno, 2004).

The use of benzimidazole fungicides, such as methyl thiophanate and sterol demethylation inhibitor fungicides (DMIs), is the main preharvest strategy adopted for disease control in peaches (Hou et al., 2010). Some of these fungicides, such as iprodione and triforine, are also registered for postharvest use (Ministério da Agricultura, Pecuária e Abastecimento [MAPA], 2018).

The most commonly used technology for preserving quality and prolonging postharvest life in stone fruits is refrigerated storage, as it reduces respiration, ethylene production, and water loss, delays maturation, and prevents the development of rotting (Kader \& Mitchell, 1989a,b). In fruit growing, biostimulants that inhibit the synthesis or action of ethylene have been used to retard ripening and preserve fruit quality during storage. In plums, Steffens et al. (2011) found that the preharvest application of aminoethoxyvinylglycine (AVG) and gibberellic acid $\left(\mathrm{GA}_{3}\right)$ influenced fruit quality after refrigerated storage when applied alone. Luo, Chen and Xie (2011) verified the effect of salicylic acid on plums; the treated fruits presented a delay in the climacteric peak and the inhibition of respiration and ethylene production due to delayed polyphenoloxidase (PPO) and peroxidase (POD) activity and lower polyamine (PA) levels. A lower incidence of fungal diseases was also observed.

However, the use of synthetic products to delay ripening and senescence and to control microorganism attacks has been restricted and eliminated from the postharvest process because such compounds may pose health risks and cause environmental impacts. Therefore, the development of more sustainable technologies that can reduce these harms is of great importance.

The use of algae extracts in agriculture has grown because they are an alternative to the use of 
chemical fertilizers in agricultural systems and do not cause environmental impacts (Khan et al., 2009; Craigie, 2011; Arioli, Mattner, \& Winberg, 2015). A considerable portion of the products derived from the more than 15 million metric tons of marine algae harvested annually are used as biostimulants in agriculture, with approximately 25 products being marketed globally (Food and Agriculture Organization [FAO], 2014).

In Brazil, there are no official surveys of the number of marketed products. However, the use of algae extracts in national agriculture is already regulated by Decree No. 4,954 of January 14, 2004, which classifies algae extracts as a complexing agent in fertilizer formulations for foliar and fertigation applications (Decreto n. 4.954, 2004). The macroalga Ascophyllum nodosum stands out among the marine species commonly used in agricultural production. This seaweed has been extensively studied for its properties that support applications from improving plant development to use in human and animal feeding (Khan et al., 2009; Gupta \& Abu-Ghannam, 2011).

Biostimulants derived from A. nodosum extract contain macro- and micronutrients, amino acids and phytohormones such as auxins, cytokinins, gibberellins and abscisic acids, as well as compounds capable of stimulating the production of these hormones by plants (Khan et al., 2009; MacKinnon, Hiltz, Ugarte, \& Craft, 2010; Sharma et al., 2012). The extract of this alga has also been shown to increase plant tolerance to abiotic and biotic stresses, as shown by reductions in disease occurrence and increases in the activity of enzymes related to plant defense mechanisms (Jayaraman, Norrie, \& Punja, 2011).

In this context, the objective of this work was to evaluate the effect of the application of an extract of A. nodosum on the postharvest quality of plums of the cultivars Irati and Reubennel and on brown rot severity and incidence in fruits inoculated with $M$. fructicola in cultivar Reubennel.

\section{Materials and Methods}

Plums of the cultivars Irati and Reubennel (Prunus salicina) were obtained from a commercial orchard in the municipality of Arapoti, Paraná state, Brazil, at $24^{\circ} 07^{\prime} 20^{\prime \prime} \mathrm{S}$ and $49^{\circ} 46^{\prime} 51^{\prime \prime} \mathrm{W}$ and an altitude of $850 \mathrm{~m}$. The regional climate is classified as Cfa in the Köppen classification, and the soil is classified as typical dystrophic red latosol with very clayey texture (Santos et al., 2006). At the time of the experiment, the orchard was four years old. The plants were grafted on 'A9' rootstock with $5.0 \times 2.5$ $\mathrm{m}$ spacing, and trained in vase system.

\section{Effect of A. nodosum algae extract on the postharvest quality of plums}

For each plum cultivar, treatment consisted of the commercial product Algamare ${ }^{\circledR}$ at a concentration of $0,0.1,0.2,0.3$ or $0.4 \mathrm{~mL} \mathrm{~L}^{-1}$ (Microquímica, Campinas, SP, Brazil). The experimental design was completely randomized with five treatments and five replicates, and each replicate consisted of five fruits. The commercial product is presented as a homogenous suspension for foliar application and is recommended as foliar fertilizer for several agricultural crops; it is obtained by alkaline hydrolysis of the extract of $A$. nodosum algae (Microquímica, 2018).

The fruits were collected at the physiological maturation stage when the surface of their skin was $80 \%$ red. After transport, abnormal fruits and fruits with pests or diseases were removed from the analysis. The disinfestation of the fruits was carried out in $0.1 \%$ sodium hypochlorite $(\mathrm{NaClO})$ for 60 minutes and 70\% alcohol for 30 minutes, with subsequent rinsing in distilled water (Alfenas \& Mafia, 2007). The fruits were then placed on a workbench at room temperature until they were completely dry.

Subsequently, the fruits were packed in nylon nets, immersed for one minute in solutions containing the extract at the different concentrations, and airdried. The fruits were then kept in a cold room for 
15 (cv. Irati) or 30 days (cv. Reubennel) and under ambient conditions for two additional days. These storage periods were based on preliminary tests of each variety. The cold storage conditions during the experiment were $2.5 \pm 2.0^{\circ} \mathrm{C}$ and $90 \pm 5 \% \mathrm{RH}$. After the storage period, the following characteristics were evaluated:

Weight loss: Before storage, the fruits were weighed with a semi-analytical balance, and the results are expressed in grams (g). The mass loss after storage was expressed as a percentage of the initial sample weight.

Pulp firmness: Pulp firmness was determined using a digital penetrometer (FR-5120 Lutron) with a $6 \mathrm{~mm}$ tip at two opposite points of the equatorial region of the fruits after epicarp removal. The results are expressed in Newtons $(\mathrm{N})$.

Titratable acidity (TA): TA was determined by potentiometric titration. A solution containing 10 $\mathrm{g}$ of a diluted fruit pulp sample was homogenized in $40 \mathrm{~mL}$ of distilled water and titrated with $0.1 \mathrm{~N}$ sodium hydroxide solution $(\mathrm{NaOH})$ until $\mathrm{pH} 8.1$ was reached. The data are expressed in milligrams (mg) of citric acid per $100 \mathrm{~g}$ of pulp.

Total soluble solids (TSS): A digital automatic temperature compensation refractometer was used on juice extracted from the fruit samples. The results are expressed as a percentage. The TSS/TA ratio was determined as the ratio between the total soluble solids content and the titratable acidity.

Total phenolic compounds: The total phenolic content was determined by the Folin-Ciocalteu method, according to Bucic-Kojic, Planinic, Thomas, Bilic and Velic (2007). A $5 \mathrm{~g}$ sample of plum pulp was homogenized with $50 \mathrm{~mL}$ of $50 \%$ ethanol in a blender for 2 minutes. The solution was centrifuged for 5 minutes, and a $0.2 \mathrm{~mL}$ aliquot was taken from the supernatant, placed in a test tube, and wrapped in aluminum paper. Then, $1.8 \mathrm{~mL}$ of distilled water plus $10 \mathrm{~mL}$ of $10 \%$ Folin-Ciocalteu solution was added. Between 30 seconds and 8 minutes later, 8 $\mathrm{mL}$ of $7.5 \%$ sodium carbonate solution $\left(\mathrm{Na}_{2} \mathrm{CO}_{3}\right)$ was added. The tubes containing the solution were stirred and kept in the dark for 2 hours. The reading was carried out on a spectrophotometer at $765 \mathrm{~nm}$ using all the reagents without the aliquot of the centrifuged sample with $1.8 \mathrm{~mL}$ of distilled water added. Gallic acid (GAE) was used as a standard, establishing a curve at concentrations of $0.2,0.4$, 0.6, 0.8, 1.0 and $1.2 \mathrm{mg} \mathrm{L}^{-1}$.

Pectin methylesterase (PME): The crude enzyme extract was prepared according to the methodology described by Pressey and Avants (1982) and Jen and Robinson (1984). Approximately $4 \mathrm{~g}$ of plum pulp was weighed out, and $8 \mathrm{~mL}$ of $0.2 \mathrm{~N}$ sodium chloride $(\mathrm{NaCl})$ was added. The extract was placed in the freezer $\left(-18{ }^{\circ} \mathrm{C}\right)$ until quantification. The activity of the PME enzyme was measured using a modification of the method of Rouse and Atkins (1955), cited by Jen and Robinson (1984), in which a unit of PME activity is defined as the amount capable of catalyzing the demethylation of pectin corresponding to the consumption of one nmol of $0.001 \mathrm{~N} \mathrm{NaOH}$ in 10 minutes. For the quantification, $30 \mathrm{~g}$ of the reaction solution (1 $\mathrm{g} \mathrm{mL}^{-1}$ of citric pectin added to $100 \mathrm{~mL}$ of $0.2 \mathrm{~N}$ $\mathrm{NaCl}$ ) was added to $4 \mathrm{~mL}$ of the enzyme extract, and the solution was calibrated to $\mathrm{pH} 7.0$ with solutions of $\mathrm{NaOH} 1 \mathrm{~N}$ and acetic acid to increase and decrease the $\mathrm{pH}$, respectively. The PME activity changes the $\mathrm{pH}$ value of the solution, and with higher enzymatic activity, the solution shows a $\mathrm{pH}$ reduction. Therefore, when the solution had a $\mathrm{pH}$ of 7.0, titration was carried out with a solution of 0.001 $\mathrm{N} \mathrm{NaOH}$ for 10 minutes. The data are expressed as $\mathrm{nmol} \mathrm{NaOH} \mathrm{g} \mathrm{g}^{-1} \mathrm{~min}^{-1}$. The enzymatic activity was quantified in duplicate to improve the credibility of the data.

Polygalacturonase (PG): The enzymatic extract was produced by adding $5 \mathrm{~mL}$ of water, $5 \mathrm{~mL}$ of $1 \mathrm{M} \mathrm{NaCl}$ (both at $4{ }^{\circ} \mathrm{C}$ ) and $5 \mathrm{~g}$ of fruit pulp, adjusting the $\mathrm{pH}$ to 6.0 with the aid of a solution of $1 \mathrm{~N} \mathrm{NaOH}$. The sample was centrifuged for 10 minutes $(6,000 \mathrm{RPM})$ at $4{ }^{\circ} \mathrm{C}$, and the supernatant was placed in a freezer $\left(-18^{\circ} \mathrm{C}\right)$ until the enzyme 
activity was determined. Determination of $\mathrm{PG}$ activity was performed by incubating $1000 \mu \mathrm{L}$ of the enzyme extract in $3 \mathrm{~mL}$ of $1 \%$ citrus pectin (diluted in $0.05 \mathrm{M}$ sodium acetate buffer, $\mathrm{pH}$ 5.0) and $1 \mathrm{~mL}$ of the sodium acetate buffer solution $(0.05$ $\mathrm{M}, \mathrm{pH}$ 5.0). The sample was then kept for 2 hours in a water bath at $30^{\circ} \mathrm{C}$. First, the pectin and the buffer solution were added to a water bath 5 minutes before depositing the extract for solution acclimatization. After the extract was added to the water bath tubes, a $1 \mathrm{~mL}$ aliquot of this solution (pectin, buffer and extract) was immediately withdrawn, and $1 \mathrm{~mL}$ of the dinitrosalicylic acid reagent (DNS) was added (the DNS solution was prepared from the mixture of solutions A and B in $100 \mathrm{~mL}$ of deionized water). Solution A was prepared with $1 \mathrm{~g}$ of dinitrosalicylic acid diluted in $30 \mathrm{ml}$ of distilled water at $30^{\circ} \mathrm{C}$. Solution B consisted of $30 \mathrm{~g}$ of potassium tartrate diluted in $20 \mathrm{~mL}$ of $2 \mathrm{~N} \mathrm{NaOH}$ at $40{ }^{\circ} \mathrm{C}$. After preparation, the DNS was stored in amber glass. This state was characterized as time 0 , that is, without PG activity. This time was used to zero the spectrum for each corresponding incubated sample. The tubes of time zero were placed in a dark environment for 2 hours, similar to the samples that were incubated in a water bath. After the incubation period, a 1 $\mathrm{mL}$ aliquot of the working sample was withdrawn and added to $1 \mathrm{~mL}$ of DNS in $2.0 \mathrm{~mL}$ Eppendorf tubes and centrifuged for 10 minutes $\left(25^{\circ} \mathrm{C}\right.$, at 6,000 RPM). The solution was then placed in test tubes and heated in a water bath for 5 minutes at 30 ${ }^{\circ} \mathrm{C}$, corresponding to time zero. Subsequently, the samples were refrigerated in a water bath at room temperature $\left(25^{\circ} \mathrm{C}\right)$, and $10 \mathrm{~mL}$ of distilled water was added. The determination of reducing sugars was carried out according to the methodology described in Miller (1959) using galacturonic acid as a standard. The reading was carried out in a spectrophotometer at $540 \mathrm{~nm}$. The enzyme activity was determined by the amount of polygalacturonic acid produced, which was compared to the values obtained in a standard line previously prepared with the same acid. The activity of PG was quantified in duplicate, and the data are expressed in $\mathrm{U} \mathrm{mL}^{-1}$.
The results were submitted to analysis of variance, and when significant, they were adjusted by polynomial regression models $(p<0.05)$. The software used for statistical analysis was SISVAR 5.3 (Ferreira, 2011).

Effects of postharvest treatment with A. nodosum extract on the occurrence of brown rot in 'Reubennel' plums

The treatments consisted of postharvest applications of $0,0.1,0.2,0.3$ and $0.4 \mathrm{~mL} \mathrm{~L}^{-1}$ of the commercial product Algamare ${ }^{\circledR}$, based on $A$. nodosum algae extract, to 'Reubennel' plum fruits inoculated with $M$. fructicola. A standard treatment with iprodione $(150 \mathrm{~mL}$ of the commercial product Rovral ${ }^{\circledR}$ in $100 \mathrm{~L}^{-1}$ water, Food Machinery Company [FMC Agrícola] (2018) was further performed. The experimental design was completely randomized, with six treatments and five replicates, and each experimental plot consisted of six fruits. For 'Irati', there were not enough fruits for inoculation or available isolates for inoculation. Therefore, this test was performed only for one variety.

The application was performed as described for the quality experiment. After the application of the A. nodosum extract treatments, the fruits were left on a workbench to dry naturally. Later, inoculation with $M$. fructicola was performed. To guarantee infection, wounds were made at two equidistant points in the equatorial region of the fruits, $2 \mathrm{~mm}$ deep, with a sterilized needle. After injury, the fruits were inoculated by spraying with a $10^{6}$ spores $\mathrm{mL}^{-1}$ spore suspension of $M$. fructicola fungus obtained from a monosporic culture isolate.

The fruits remained in the cold chamber at $2.5 \pm$ $2.0{ }^{\circ} \mathrm{C}$ and $90 \pm 5 \% \mathrm{RH}$ during a seven-day period. After this time, the fruits were placed on the bench $\left(25 \pm 5^{\circ} \mathrm{C}\right.$ and $50 \pm 10 \% \mathrm{RH}$ ) and wrapped for the first 24 hours with a plastic bag to promote a humid environment that was favorable to the development of the disease. 
The following characteristics were evaluated: area below the disease incidence progress curve (ABDIPC), area below the disease severity progress curve (ABDSPC) and disease index (DI).

ABDIPC and ABDSPC: On the second day after the removal of the fruits from the cold chamber, daily evaluations of lesion evolution were initiated, and measurements were made of the lesion diameter in two transverse areas using a digital caliper. The evaluations were completed on the ninth day, when most of the control treatment fruits were overtaken by the disease. The incidence (percentage of fruits with lesions) and severity (mean diameter of lesions developed) of the disease were determined. The lesion mean diameter and incidence were transformed into a percentage using a standard diameter of $4.7 \mathrm{~mm}$ for all fruits. The percentage of the fruit area with symptoms was expressed as the ABDSPC, and the percentage of fruits with lesions were expressed as the ABDIPC, according to the methodology (Campbell \& Madden, 1990).

DI: The DI was determined using grades from 0 to 4 , according to the methodology proposed by Carvalho, Cunha, Chalfun and Moura (2009), in which the occurrence and lesion area consist of the following criteria: 1) lesions covering from 0 to $25 \%$ of the fruit; 2) lesions covering 26 to $50 \%$ of the fruit; 3) lesions covering 51 to $75 \%$ of the fruit; and 4) lesions $>75 \%$ of the fruit. With the aid of these notes, the DI, as described by McKinney (1923), cited in Cirulli and Alexander (1966), was calculated according to the following equation:

$$
D I=\sum \frac{(f v) 100}{n x}
$$

$\mathrm{DI}=$ Disease index;

$f=$ Number of fruits in each category of infection;

$\mathrm{v}=$ Degree of infection;

$\mathrm{n}=$ Total number of inoculated fruits;

$\mathrm{x}=$ Maximum degree of infection.

The results were submitted to analysis of variance and, when significant, were compared by the ScottKnott test and adjusted polynomial regression models ( $\mathrm{p}<0.05$ ). For ABDIPC, ABDSPC and DI, a Dunnett test was performed in which all treatments were compared to the control. The software used for statistical analysis was SISVAR 5.3 (Ferreira, 2011).

\section{Results}

Effect of A. nodosum extract on postharvest plum quality

The initial values obtained in the physicohemical evaluations of the 'Irati' and 'Reubennel' fruits are presented in Table 1. Comparing these traits after storage, significant differences were found for the majority of the evaluations, except for the titratable acidity and phenolic compound contents in 'Irati' plums and the total soluble solids for 'Reubennel' plums.

\section{Table 1}

\section{Harvest and after storage values of physical-chemical evaluations in plums cvs. Irati and Reubennel}

\begin{tabular}{lcccc}
\hline Characteristics & \multicolumn{2}{c}{ Irati } & \multicolumn{2}{c}{ Reubennel } \\
\hline & Harvest & After storage & Harvest & After storage \\
\hline Firmness of the pulp (N) & 31.7 & $11.0 * *$ & 39.4 & $5.1^{* *}$ \\
Total soluble solids (\%) & 9.03 & $10.9^{*}$ & 12.0 & $12.9^{\mathrm{ns}}$ \\
Titratable acidity (\%) & 1.07 & $0.98^{\mathrm{ns}}$ & 0.98 & $0.41^{*}$ \\
Relation TSS/TA & 10.3 & $10.82^{*}$ & 12.9 & $31.5^{* *}$ \\
Phenolic compounds (mg gallic acid $\left.100 \mathrm{~g} \mathrm{~g}^{-1}\right)$ & 57.0 & $62.1^{\mathrm{ns}}$ & 31.9 & $62.1^{* *}$ \\
Pectinamethylesterase (nmol g- $\left.\mathrm{min}^{-1}\right)$ & 475.4 & $1228.6^{* *}$ & 639.4 & $326.9^{* *}$ \\
Polygalacturonase $\left(\mathrm{U} \mathrm{mL} \mathrm{mL}^{-1}\right)$ & 38.9 & $8.22^{* *}$ & 40.8 & $22.5^{* *}$ \\
\hline
\end{tabular}

ns $=$ not significant; $*=\mathrm{p} \leq 0.05 ; * *=\mathrm{p} \leq 0.01$. 
In 'Irati' plums, for the evaluation performed after 15 days in a cold room and two days at ambient conditions, differences between the treatments were found for the total phenolic compound content and the activity of polygalacturonase (PG) (Figure 1). The $A$. nodosum extract concentration had a positive linear effect on the total phenolic compound content
(Figure 1A). The PG activity changed as a quadratic function with the increasing extract concentration, with the highest activity estimated at a concentration of $0.31 \mathrm{U} \mathrm{mL}^{-1}$ (Figure 1B). Polygalacturonase activity was higher after storage than in the initial analysis (Table 1).

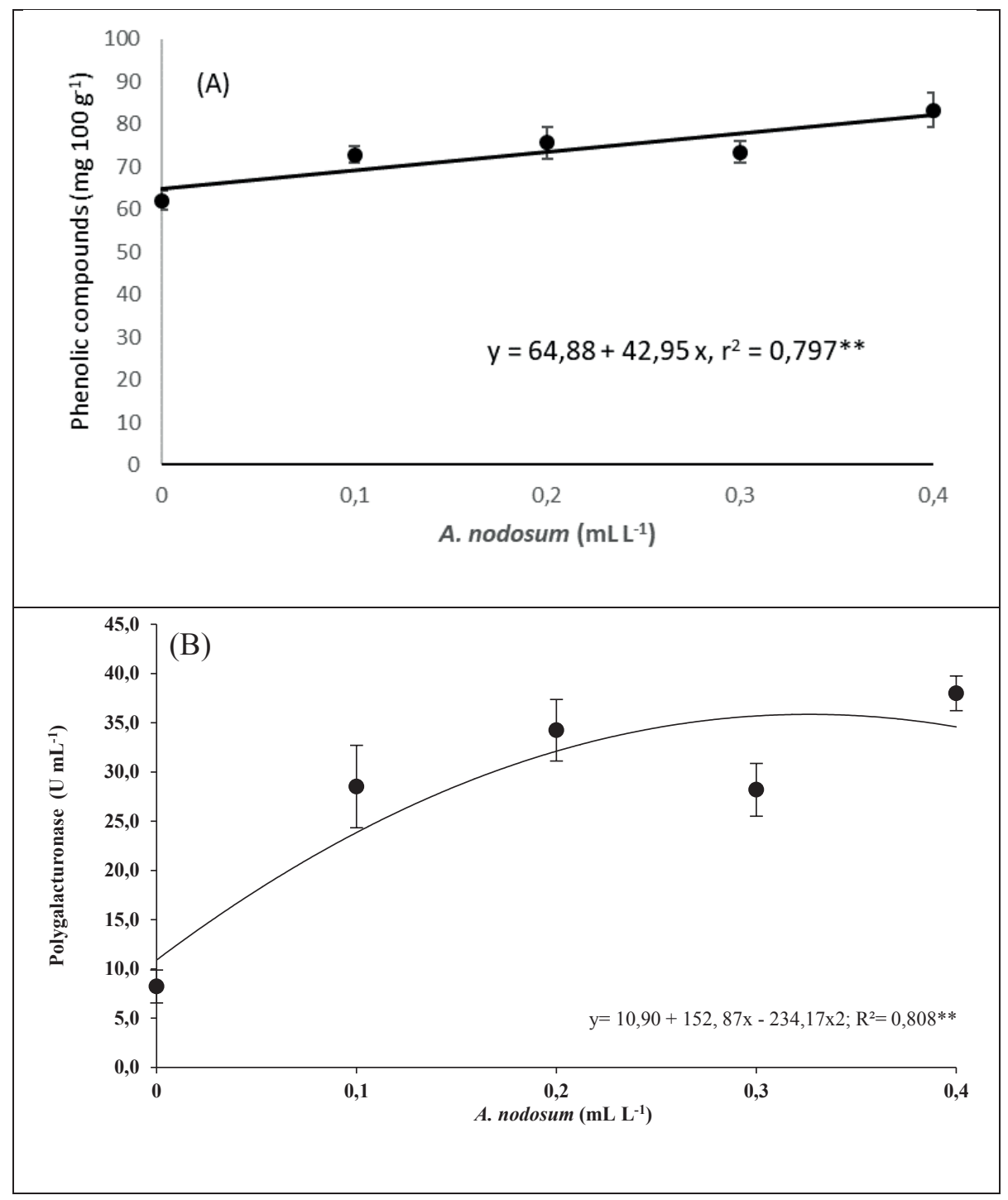

Figure 1. Content of total phenolic compound (A), and polygalacturonase activity (B) of 'Irati' plums treated with $A$. nodosum extract and stored for 15 days at $2.5 \pm 2.0^{\circ} \mathrm{C}+$ 2 days at room temperature. Vertical bars indicate standard deviation.

In 'Reubennel' plums, for the evaluation effect of the treatments on the mass loss, total performed after 30 days in the cold room and two soluble solids content or PG activity. days at ambient conditions, there was no significant 
For the results of the titratable acidity analysis, considering the initial values, there was a reduction in titratable acidity after the storage period (Table 1). In relation to the treatment effects, a positive linear effect on TA as a function of the algae extract concentration was observed (Figure 2A). The TSS/ TA ratio values more than doubled after storage, and the extract concentration and TSS/TA ratio showed a quadratic relationship. The lowest value was found at the $0.4 \mathrm{~mL} \mathrm{~L}^{-1}$ concentration of Algamare ${ }^{\circledR}$ (Figure 2B).
For pulp firmness, there was a reduction after storage compared to the initial values. In addition, the pulp firmness varied quadratically with the $A$. nodosum concentration, with a minimum value at a concentration of $0.4 \mathrm{~mL} \mathrm{~L}^{-1}$ (Figure 2C). For PME enzyme activity, the values were lower after storage than in the initial analysis, and a positive linear effect was observed as a function of the Algamare ${ }^{\circledR}$ concentration (Figure 2D).

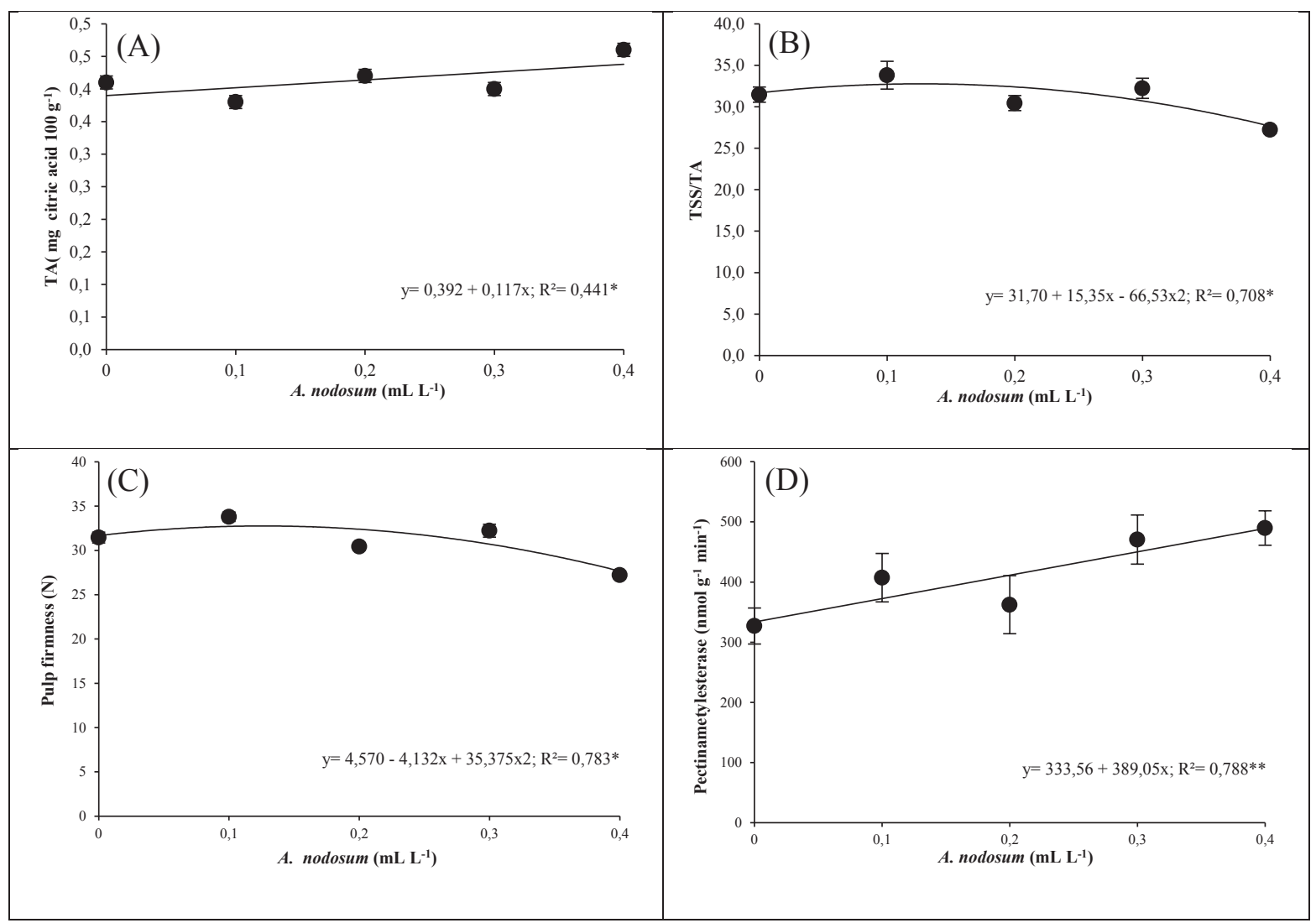

Figure 2. Titratable acidity (A), TSS/TA ratio (B), firmness of pulp (C) and activity of pectinamethylesterase (D) of 'Reubennel' plums treated with $A$. nodosum extract and stored for 30 days at $2.5 \pm 2.0^{\circ} \mathrm{C}+2$ days at room temperature. Vertical bars indicate standard deviation.

Effect of postharvest treatment with A. nodosum extract on the occurrence of brown rot in 'Reubennel' plums.

For the evaluations of the incidence and severity of brown rot in Reubennel plum fruits inoculated with $M$. fructicola, there was a quadratic effect as a function of the extract concentration for the ABDIPC, ABDSPC and DI results. Minimum values were observed at the concentration of 0.4 $\mathrm{mL} \mathrm{L}^{-1}$, and the effects of this dose did not differ 
from those of the standard treatment with iprodione fungicide. Both treatments significantly reduced the incidence and severity by approximately $50 \%$ and the DI by $40 \%$ in 'Reubennel' plums compared to those in the control (Figures 3A, 3B and 3C).

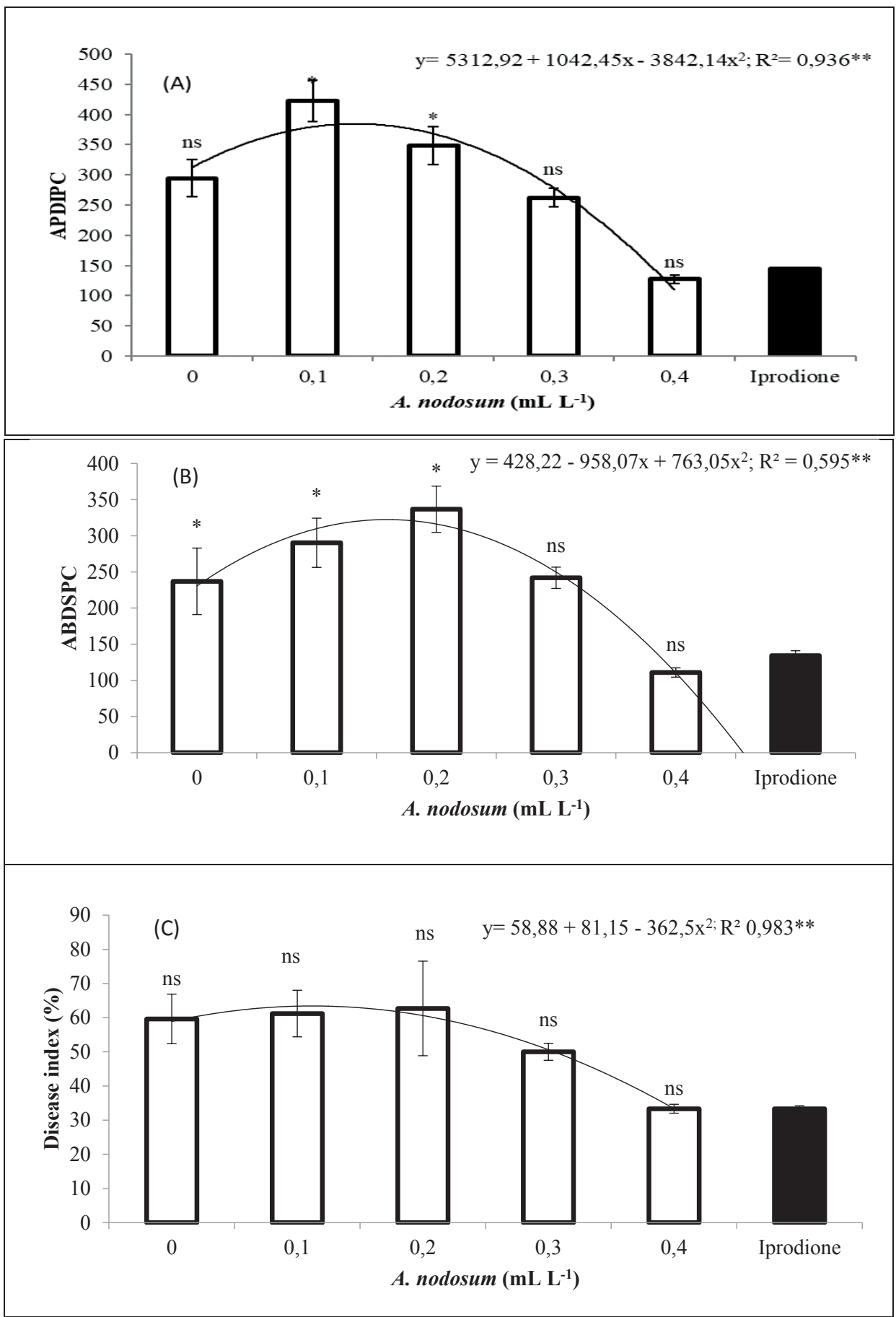

Figure 3. Area below the disease incidence progress curve (A), area below the disease severity progress curve (B) and disease index (C) of brown rot in 'Reubennel' plums treated with different concentrations of Ascophyllum nodosum extract or iprodione. * significant at $5 \%$ probability level by Dunnett test. ns $=$ not significant. 


\section{Discussion}

Effect of A. nodosum algae extract on postharvest plum quality

In general, the application of $A$. nodosum extract altered some physicochemical characteristics of the plum fruits after the storage period, and the effect was different in the two cultivars. The different effects observed are directly related to the composition of the A. nodosum extract, which contains phytohormones, mainly auxins and cytokinins (Durand, Briand, \& Meyer, 2003; Zhang \& Ervin, 2004, 2008), as well as betaines (MacKinnon et al., 2010), gibberellins, abscisic acid, jasmonic acid, polyamines and alginates (Tarakhovskaya, Maslov, \& Shishova, 2007). In addition to organic and inorganic compounds, which are essential nutrients to the development of plants, the extract also contains carbohydrates and amino acids (Rioux, Turgeon, \& Beaulieu, 2007; Khan et al., 2009).

The higher initial titratable acidity and the lower TSS/TA ratio observed in the cv. Irati may have been indicative of delayed maturation and senescence. Normally, the titratable acidity of fruit decreases after harvesting and, consequently, the TSS/TA ratio increases. This decrease occurs due to respiration, which continues to occur even after harvesting. Substrates, including acids, are used in respiration to generate energy and maintain the vital processes in the fruit (Pech, 2002). Many phytohormones in the A. nodosum extract, such as auxins, cytokinins and gibberellins, can delay ripening and, consequently, the senescence of fruits (Chitarra \& Chitarra, 2005).

The increase in the contents of total phenolic compounds in 'Irati' plums treated with algae extract was another change during the storage period. Ferri et al. (2004) found that the content of phenolic compounds decreased during maturation in persimmons; however, the decrease in phenolic compound contents was more notable in fruits not treated with $\mathrm{GA}_{3}$ before harvest.
The A. nodosum extract treatment increased the activity of enzymes related to cell wall degradation (PG and PME). Consequently, a loss of pulp firmness was verified in the Reubennel cultivar. Although this is not a desirable effect in postharvest storage conditions, it did not compromise the final plum quality; the fruit attained a minimum firmness of 27 $\mathrm{N}$ after storage, which is a level recommended for commercial sale (Rees, Farrell, \& Orchard, 2012). Kohatsu (2007) studied the application effect of plant regulators on melon crops (Cucumis melo L. var. Reticulatus Naud.) and found that fruits treated with $\mathrm{GA}_{3}$ had less PME activity during the whole storage period, with values not exceeding 700 $\mathrm{nmol} \mathrm{g}{ }^{-1} \mathrm{~min}^{-1}$. Other studies have found enzymatic activity higher than $800 \mathrm{nmol} \mathrm{g}^{-1} \mathrm{~min}^{-1}$, reaching up to $1,057 \mathrm{nmol} \mathrm{g}^{-1} \mathrm{~min}^{-1}$ in the latest research.

Effect of postharvest treatment with A. nodosum extract on the occurrence of brown rot in 'Reubennel' plums

Reductions in the incidence and severity of brown rot were found in plums treated with some of the tested doses of $A$. nodosum. Other studies have also verified such effects. Jayaraj, Wan and Rahman (2008) worked with carrot plants (Daucus carota) in a protected environment; the carrots were sprayed with $A$. nodosum extract $(0.2 \%)$ and salicylic acid $(100 \mathrm{mM})$ before inoculation with the fungi Alternaria radicina and Botrytis cinerea applied 10 and 20 days after inoculation. The authors found a reduction in disease development of up to $57 \%$ against $A$. radicina and $53.5 \%$ against $B$. cinerea.

The possible effect of $A$. nodosum extracts on disease control may be related to the induction of plant resistance mechanisms to biotic and abiotic stresses. The increase in the phenolic compounds found in this work is a strong indicator of this effect. One plant defense mechanism is the production and accumulation of phytoalexins, a type of phenolic compound that acts as an antimicrobial substance (Naczk \& Shahidi 2004; Oliveira, Varanda, \& Félix, 2016). 
This was also observed in A. nodosum-treated cucumber plants (Cucumis sativus), which showed a lower incidence of diseases caused by Didymella applanata, Fusarium oxysporum and B. cinerea, in addition to increases in the activities of chitinase (EC 3.2.1.14), peroxidase (EC 1.11.1, POD), polyphenoloxidase (EC 1.14.18.1, PFO) and lipoxygenase (EC 1.13.11, IPR), which are directly related to plant defense (Jayaraman et al., 2011).

The increase in brown rot in plums treated with lower concentrations of $A$. nodosum could be attributed to its organic content, which could stimulate fungal development without increasing plant defense responses.

\section{Conclusions}

After cold storage of 'Reubennel' plums, no significant effect of $A$. nodosum extract was noted on mass loss, total soluble solids content or PG activity. Nevertheless, the treatments increased titratable acidity and pectin methylesterase activity and decreased the TSS/TA ratio and fruit firmness.

For 'Irati' plums, A. nodosum extract only increased the total phenolic compound content and polygalacturonase activity after 15 days of cold storage and two days at ambient conditions.

The extract of $A$. nodosum at a concentration of $0.4 \mathrm{~mL} \mathrm{~L}^{-1}$ reduced the incidence and severity of brown rot disease in 'Reubennel' plums with a level of control similar to that of the fungicide iprodione.

\section{References}

Alfenas, A. C., \& Mafia, R. G. (2007). Métodos em fitopatologia. Viçosa, MG: Editora UFV.

Arioli, T., Mattner, S. W., \& Winberg, P. C. (2015). Applications of seaweed extracts in Australian agriculture: Past, present and future. Journal of Applied Phycology, 27(5), 2007-2015. doi: 10.1007/ s10811-015-0574-9
Bosshard, E., Hilber-Bodmer, M., Schärer, H. J., Bünter, M., \& Duffy, B. (2006). First report of the quarantine brown rot pathogen Monilinia fructicola on imported stone fruits in Switzerland. Plant Disease, 90(12), 1554-1563. doi: 10.1094/PD-90-1554C

Bucic-Kojic, A., Planinic, M., Thomas, S., Bilic, M., \& Velic, D. (2007). Study of solid-liquid extraction kinetics of total polyphenols from grape seeds. Journal of Food Engineering, 81(1), 236-247. doi: 10.1016/j.jfoodeng.2006.10.027

Campbell, C. L., \& Madden, L. V. (1990). Monitoring epidemics: diseases. In C. L. Campbell, L. V. Madden (Eds.), Introduction to plant disease epidemiology (pp. 107-128). New York: John Wiley \& Sons.

Carvalho, V. L. de, Cunha, R. L. da, Chalfun, N. N. J., \& Moura, P. H. A. (2009). Alternatives for postharvest control of brown rot and soft rot in peach fruits. Revista Brasileira de Fruticultura, 31(1), 78-83. doi: 10.1590/S0100-29452009000100012

Chitarra, M. I. F., \& Chitarra, A. B. (2005). Pós-colheita de frutas e hortaliças: fisiologia e manuseio. (2a ed.). Lavras: Editora UFLA.

Cirulli, M., \& Alexander, L. J. A. (1966). A comparison of pathogenic isolates of Fusarium oxysporum $\mathrm{f}$. sp. lycopersici and different sources of resistance in tomato. Phytopathology, 56, 1301-1304.

Craigie, J. S. (2011). Seaweed extract stimuli in plant science and agriculture. Journal of Applied Phycology, 23(3), 371-393. doi: 10.1007/s10811010-9560-4

Crisosto, C. H., \& Mitchell, F. G. (2011). Postharvest handling systems: stone fruits. In A. A. Kader (Ed.), Postharvest technology of horticultural crops (pp. 345-351). Richmond: University of California.

De Cal, A., Gell, I., Usall, J., Viñas, I., \& Melgarejo, P. (2009). First report of brown rot caused by Monilinia fructicola in peach orchards in Ebro Valley, Spain. Plant Disease Journal, 93(7), 763-763. doi: 10.1094/ PDIS-93-7-0763A

Decreto n. 4.954, de 14 de janeiro de 2004. Altera o Anexo ao Decreto n. 4.954, de 14 de janeiro de 2004, que aprova o Regulamento da Lei n. 6.894, de 16 de dezembro de 1980, que dispõe sobre a inspeção e fiscalização da produção e do comércio de fertilizantes, corretivos, inoculantes, ou biofertilizantes, remineralizadores e substratos para plantas destinados à agricultura. Recuperado de https://www2.camara.leg.br/legin/fed/decret/ 2004/decreto-4954-14-janeiro-2004-497758normaatualizada-pe.pdf 
Durand, N., Briand, X., \& Meyer, C. (2003). The effect of marine bioactive substances (N PRO) and exogenous cytokinins on nitrate reductase activity in Arabidopsis thaliana. Physiologia Plantarum, 119(4), 489-493. doi: 10.1046/j.1399-3054.2003.00207.x

Ferreira,D.F.(2011). Sisvar: a computerstatistical analysis system. Ciência e Agrotecnologia, 35(6), 1039-1042. doi: $10.1590 /$ S1413-70542011000600001

Ferri, V. C., Rinaldi, M. M., Silva, J. A., Lucheta, L., Marini, L., \& Rombaldi, C. V. (2004). Ácido giberélico no retardamento da maturação de caquis (Diospyrus kaki L.) cultivar Fuyu. Ciência $e$ Tecnologia dos Alimentos, 24(1), 1-5. doi: 10.1590/ S0101-20612004000100001

Food Machinery Company, FMC Agrícola (2018). Produtos: Rovral. Relatório do produto. Recuperado de https://www.fmcagricola.com.br/bula_geraPDF. aspx? $\operatorname{cod}=10$

Food and Agriculture Organization (2014). Yearbook of fisheries and aquaculture statistics. Retrieved from http://www.fao.org/3/a-i3740t.pdf

Gupta, S., \& Abu-Ghannam, N. (2011). Recent developments in the application of seaweeds or seaweed extracts as a means for enhancing the safety and quality attributes of foods. Innovative Food Science \& Emerging Technologies, 12(4), 600-609. doi: 10.1016/j.ifset.2011.07.004

Hou, D., Yan, C., Liu, H., Ge, X., Xu, W., \& Tian, P. (2010). Berberine as a natural compound inhibits the development of brown rot fungus Monilinia fructicola. Crop Protection, 29(9), 979-984. doi: 10.1016/j.cropro.2010.05.015

Jayaraj, J., Wan, A., Rahman, M., \& Punja, Z. K. (2008). Seaweed extract reduces foliar fungal diseases on carrot. Crop Protection, 27(10), 1360-1366. doi: 10.1016/j.cropro.2008.05.005

Jayaraman, J., Norrie, J., \& Punja, Z. K. (2011). Commercial extract from the brown seaweed Ascophyllum nodosum reduces fungal diseases in greenhouse cucumber. Journal of Applied Phycology, 23(3), 353-361. doi: 10.1007/s10811-010-9547-1

Jen, J. J., \& Robinson, M. L. (1984). Pectolytic enzymes in sweet bell peppers (Capsicum annuит L.). Journal of Food Science, 49(4), 1045-1087. doi: 10.1111/j.1365-2621.1984.tb10398.x

Kader, A. A. (2011). Postharvest biology and technology: an overview. In A. A. Kader (Ed.), Postharvest technology of horticultural crops (pp. 39-48). Richmond: University of California.
Kader, A. A., \& Mitchell, F. G. (1989a). Postharvest physiology. In J. H. LaRue, \& R. S. Johnson (Eds.), Peaches, plums and nectarines: growing and handling for fresh Market (pp. 158-164). Davis: University of California.

Kader, A. A., \& Mitchell, F. G. (1989b). Factors affecting deterioration rate. In J. H. LaRue, \& R. S. Johnson (Eds.), Peaches, plums and nectarines: growing and handling for fresh Market (pp. 165-178). Davis: University of California.

Khan, W., Rayirath, U. P., Subramanian, S., Jithesh, M. N., Rayorath, P., Hodges, D. M.,... Prithiviraj, B. (2009). Seaweed extracts as biostimulants of plant growth and development. Journal of Plant Growth Regulation, 28(4), 386-399. doi: 10.1007/s00344009-9103-x

Kohatsu, D. S. (2007). Efeitos de reguladores vegetais na qualidade de frutos de melão Rendilhado. Dissertação de mestrado, Universidade Estadual Paulista, Botucatu, SP, Brasil.

Luo, Z., Chen, C., \& Xie, J. (2011). Effect of salicylic acid treatment on alleviating postharvest chilling injury of 'Qingnai' plum fruit. Postharvest Biology and Technology, 62(2), 115-120. doi: 10.1016/j. postharvbio.2011.05.012

MacKinnon, A. S., Hiltz, D., Ugarte, R., \& Craft, C. A. (2010). Improved methods of analysis for betaines in Ascophyllum nodosum and its commercial seaweed extracts. Journal of Applied Phycology, 22(4), 489494. doi: 10.1007/s10811-009-9483-0

May de Mio, L. L., Garrido, L., \& Ueno, B. (2004). Doenças de fruteiras de caroço. In L. B. Monteiro, L. L. May de Mio, B. M. Serrat, A. C. Motta, \& F. L. Cuquel (Eds.), Fruteiras de caroço: uma visão ecológica (pp. 169-221). Curitiba: Universidade Federal do Paraná.

May de Mio, L. L., Luo, Y., \& Michailides, T. J. (2011). Sensitivity of Monilinia fructicola from Brazil to tebuconazole, azoxystrobin, and thiophanate-methyl and implications for disease management. Plant Disease, 95(7), 821-827. doi: 10.1094/PDIS-07-100511

McKinney, H. H. (1923). Influence of soil, temperature and moisture on infection of wheat seedlings by Helminthosporium sativum. Journal of Agricultural Research, 26(3), 195-217.

Microquímica (2018). Produtos: Algamare. Descrição do produto. Recuperado de http://www.microquimica. com/site/prod_algamare.htm 
Miller, G. L. (1959). Use of dinitrosalicylic acid reagent for determination of reducing sugar. Analytical Chemistry, 31(3), 426-428. doi: 10.1021/ ac60147a030

Ministério da Agricultura, Pecuária e Abastecimento. (2018). Sistema de agrotóxicos fitossanitários. Recuperado de http://agrofit.agricultura.gov.br/ agrofit_cons/principal_agrofit_cons

Naczk, M., \& Shahidi, F. (2004). Extraction and analysis of phenolics in food. Journal of Chromatography, 1054(1-2), 95-111. doi: 10.1016/S00219673(04)01409-8

Oliveira, M. D. M., Varanda, C. M. R., \& Félix, M. R. F. (2016). Induced resistance during the interaction pathogen $x$ plant and the use of resistance inducers. Phytochemistry Letters, 15(1), 152-158. doi: 10.1016/j.phytol.2015.12.011

Pech, J. C. (2002). Unravelling the mechanisms of fruit ripening and development of sensory quality thought the manipulation of ethylene biosynthesis in melon. Proceedings Nato Advanced Research Workshop on Biotechnology of the Plant Hormone Ethylene, Murcia, Spain.

Pressey, R., \& Avants, J. K. (1982). Solubilization of cell walls by tomato polygalacturonases: effects of pectinesterases. Journal of Food Biochemistry, 6(1), 57-74. doi: 10.1111/j.1745-4514.1982.tb00296.x

Rees, D., Farrell, G., \& Orchard, J. (2012). Crop postharvest: science and technology. New Jersey: John Wiley \& Sons.

Rioux, L. E., Turgeon, S. L., \& Beaulieu, M. (2007). Characterization of polysaccharides extracted from brown seaweeds. Carbohydrate Polymers, 69(3), 530-537. doi: 10.1016/j.carbpol.2007.01.009
Rouse, A. H., \& Atkins, C. D. (1955). Pectinesterase and pectin in commercial citrus juices as determined by methods used at the Citrus Experiment Station. Gainesville: University of Florida Agricultural Experiment Station.

Santos, H. G. dos, Jacomine, P. K. T., Anjos, L. H. C. dos, Oliveira, V. A. de, Coelho, M. R., Lumbreras, J. F., \& Cunha, T. J. F. (2006). Sistema brasileiro de classificação de solos. Rio de Janeiro: EMBRAPA.

Sharma, S. H. S., Lyons, G., McRoberts, C., McCall, D., Carmichael, E., Andrews, F.,... Mellon, R. (2012). Biostimulant activity of brown seaweed species from Strangford Lough: Compositional analyses of polysaccharides and bioassay of extracts using mung bean (Vigno mungo L.) and pak choi (Brassica rapachinensis L.). Journal of Applied Phycology, 24(5), 1081-1091. doi: 10.1007/s10811-011-9737-5

Steffens, C. A., Amarante, C. V. T., Chechi, R., Zanardi, O. Z., Espindola, B. P., \& Meneghini, A. L. (2011). O tratamento pré-colheita com aminoetoxivinilglicina ou ácido giberélico preserva a qualidade pós-colheita de ameixas 'Laetitia'. Bragantia, 70(1), 222-227. doi: 10.1590/S0006-87052011000100029

Tarakhovskaya, E. R., Maslov, Y. I., \& Shishova, M. F. (2007). Phytohormones in algae. Russian Journal of Plant Physiology, 54(2), 163-170. doi: 10.1134/ S1021443707020021

Zhang, X., \& Ervin, E. H. (2004). Cytokinin-containing seaweed and humic acid extracts associated with creeping bentgrass leaf cytokinins and drought resistance. Crop Science, 44(5), 1-10. doi: 10.2135/ cropsci2004.1737

Zhang, X., \& Ervin, E. H. (2008). Impact of seaweed extract-based cytokinins and zeatin riboside on creeping bentgrass heat tolerance. Crop Science, 48(1), 364-370. doi: 10.2135/cropsci2007.05.0262 
